
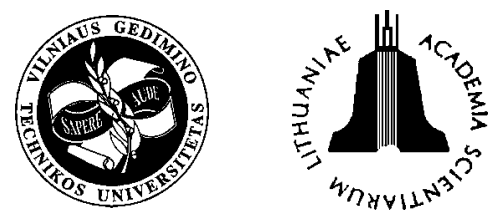

ISSN $1392-3730$

JOURNAL OF CIVIL ENGINEERING AND MANAGEMENT

http:/www.jcem.vgtu.lt

2004, Vol X, No 4, 285-293

\title{
EVALUATION OF SERVICE FROST RESISTANCE OF CERAMIC FACING TILES
}

\author{
Romualdas Mačiulaitis ${ }^{1}$, Asta Kičaite் ${ }^{1}$, Džigita Nagrockiené ${ }^{1}$, Gema Kudabienè ${ }^{2}$ \\ ${ }^{1}$ Dept of Building Materials, Vilnius Gediminas Technical University, Saulètekio al. 11, LT-10223 Vilnius, \\ Lithuania.E-mail: romualdas.maciulaitis@st.vtu.lt; smst@st.vtu.lt \\ ${ }^{2}$ Dept of Chemistry, Vilnius Pedagogical University, Studentu g. 39, LT-08106 Vilnius, Lithuania. \\ E-mail: gemak@vpu.lt
}

Received 17 March 2004; accepted 1 June 2004

\begin{abstract}
The problem of frost resistance is relevant to facing materials, especially glazed ceramic tiles. Analysing the processes of ceramic tile destruction it is important to take into account the primary destruction symptoms. New estimation of service frost resistance of ceramic tile according to residual surface and residual mass of the tile after a certain number of simulated service cycles is presented in the paper. Applying the new estimation, the forecast of frost resistance under extremely unfavourable service conditions may be performed. As for other ceramic products regarding frost resistance, one of the most important parameters is the reserve of pore volume. For a rapid estimation of service frost resistance of ceramic tile it is best to use several parameters under multiple correlation with the parameter of service frost resistance.
\end{abstract}

Keywords: service frost resistance, glazed ceramic tile, reserve of pore volume, residual mass of tile, residual surface of tile.

\section{Introduction}

Durability of partitive constructions and finishing layers of building exterior is determined by the frost resistance of materials and products applied. This is one of the main physical properties.

Usually mechanical and physical characteristics of structural and finishing materials differ. Exactly the discrepancy of structural and strength characteristics largely determines the durability of such composites in a construction [1].

For finishing building walls glazed or unglazed ceramic tiles are often used, fixed to a different base.

In real buildings the destruction of ceramic facing tile due to climatic factors is observed. The durability problem of ceramic tile or any other finish is related to the moisture in upper layers of partition construction [2]. This problem is especially relevant in the regions where a large effect of precipitation (as rain or wet snow) takes place and a cyclic temperature variation is typical. The impact of precipitation in the construction is different even in one region and depends on structural decisions, height of building, relief of the region, etc.

Recently two methods for determining the frost resistance of wall and finish materials are applied worldwide: based on volumetric and on unilateral freezing principle [2-6].

The frost resistance determination method by volumetric freezing is still widely used for all finishing_ce- ramic products. The classical volumetric freezing-thawing method remained without substantial changes till nowadays (except for variants of temperature-moisture regimes) in normative documents of many countries.

Comparing the detailed data of frost resistance obtained during unilateral freezing-thawing and volumetric freezing-thawing of ceramic brick, considerable differences were observed [3]. Performing the investigation by volumetric freezing and determining that ceramic products are frost resistant, a case is possible that the products applied in walls or partitions may destruct in a short period (several cold seasons).

A Canadian scientist [7] analysing ceramic tile has concluded that investigation of such samples by volumetric freezing is not an exact reflection of laws taking place in nature and is based only on the advantages of investigation. In this case the processes and conditions taking part under natural conditions or during service are not taken into account.

Long-lasting investigations of researchers in different countries have proved that the frost resistance parameters of ceramic brick determined by volumetric freezing-thawing cannot be compared with the parameters obtained in simulated or natural conditions [4, 6-11]. The results finally depend on the methodology applied for determining the ceramic products frost resistance. Discrepancy of heat offtake direction leads to different depth and speed of samples freezing, uneven intensity of 
moisture migration, and different mechanism_of ice crystallisation in a ceramic body. Thus different results of sample frost resistance are obtained. According to long-term investigations of Lithuanian scientists performed under natural and simulated service conditions by ten regimes of unilateral freezing the necessity to apply only the unilateral principle of heat offtake for predicting the service frost resistance of rough ceramic samples is shown $[3,6]$.

Frost resistance of laminar constructions under simulated service conditions when one of the components are glazed ceramic tiles depends on the properties of tiles (especially of open porosity) determined by production technology. Nonetheless influence is made by production technology of the construction itself; also an important factor is adhesion of tiles to the base.

Another relevant problem is the increase of frost resistance of ceramic tile to ensure the necessary durability of partitive finishing constructions. This question is complicated, because the moisture and temperature impact in different regions differs a lot and the production is necessary with a high and different grade of frost resistance. The tiles are usually glazed and this creates additional problems when solving the questions of predicting their frost resistance.

For determining the facing frost resistance the standard LST 1413.12:1998 is used in Lithuania [12]. In the standard the service conditions are divided into three main categories. The corresponding grades of frost resistance are for the categories, because the impact of service and climatic factors for constructions or masonry may be different. In Lithuania the category FIII is the most relevant. The finishing of grade $\mathrm{F}_{\mathrm{RE}} 125$ belongs to this grade. It is used under very destructive conditions because of the frequent impact of cyclic moisture and water or saline water solutions, frost and heat.

Frost resistance of ceramic products may be evaluated not only by direct determination methods, but also by the rapid ones. Applying the aforementioned methods the frost resistance of ceramic products may be evaluated during a much shorter period of time (from 3 to 10 days) [3, 13-21]. In these rapid methods of frost resistance determination the number of cycles is predicted, when the destruction of ceramic body's surface and loss of mass take place (visually observed).

Many researchers have derived the interdependence of ceramics frost resistance and diameter of the pores and capillaries and their distribution by size [22-27], when the rapid methods are applied.

Nevertheless, enough attention is not paid to the rapid determination of frost resistance of ceramic tiles. Therefore it is a topical issue to analyse the prediction of frost resistance of glazed and unglazed ceramic facing tiles by applying new criteria and principles.

The aim of this work is to analyse destruction tendencies of glazed ceramic tiles and the structural parameters influencing the service frost resistance of ceramic tiles. After determining the main structural parameters it is necessary to predict the possible destruction of ceramic tiles, when these tiles are to be employed under the conditions of category FIII, according to the loss of surface and mass or residual surface and mass.

\section{Research materials and methodology}

Different ceramic tiles have been examined. They were produced changing technological factors. The open porosity of them ranged from $9,54 \%$ to $23,08 \%$. The tiles belong to the first porosity group (their open porosity less than $26 \%$ ) [3].

Water saturation of samples in the vacuum process was performed according to well-known methods [3].

Effective porosity $\left(\mathrm{W}_{\mathrm{E}}, \%\right)$, relative wall thickness of pores and capillaries ( $\mathrm{D}$, non-dimensional magnitude), reserve of pore volume $(\mathrm{R}, \%)$, parameter of structural inhomogeneity ( $\mathrm{N}$, units) were calculated by the wellknown methods, too [3].

The amount of water sucked by capillaries under normal conditions $\left(\mathrm{G}, \mathrm{g} / \mathrm{cm}^{2}\right)$ and the height of capillary rise $(\mathrm{H}, \mathrm{cm})$ were determined. Therefore the sample was weighted after 3,10, 20, 30, 60, 90 and $120 \mathrm{~min}$ and the watering contour was marked. Amount of water absorbed in a sample was calculated by the well-known formula [3].

For a more exact structural valuation of effective pores and capillaries, ie for determining the unevenness parameter of pores and capillaries radius $\mathrm{X}$, the wellknown dependence was applied [28]:

$$
X=\frac{G}{\sqrt{t}},
$$

where $G$ - amount of the absorbed water, $\mathrm{g} ; t-$ time, $\min$.

For mathematical calculation $\mathrm{X}_{120}$ parameter was selected.

Statistical scatter of the quantitative parameter of effective pores and capillaries (U, \%) in case of minimal relative radius was calculated in this way:

$$
U=\frac{\Delta X}{X_{\min }} \cdot 100,
$$

where $\Delta \mathrm{X}$ - difference between the maximum and the minimum values; $X_{\min }$ - the minimum value.

Frost resistance of ceramic tiles was determined in two ways of unilateral freezing-thawing: ie by unilateral freezing-thawing according to LST 1272:1992, p. 3.8.3 [29] and LST 1413.12:1998 [12], when more severe conditions of the experiment were simulated.

At the beginning of unilateral freezing-thawing according to LST 1272:1992, case p. 3.8.3 the samples were soaked in water for 3 days. Then they were cooled for 4,5 hours at $15 \div 20{ }^{\circ} \mathrm{C}$ and thawed out in water for 4,5 hours. In this case the loss of sample mass ( $\mathrm{MN}, \%$ ) and the destructed surface $(\mathrm{PN}, \%)$ were determined after a certain number of freezing and thawing cycles. The 
beginning of destruction (FV) was recorded according to LST 1272:1992. Frost resistance test of ceramic tiles was carried out up to 600 cycles.

Investigation of ceramic tiles frost resistance according to LST 1413.12:1998 were performed applying the equipment of freezing-spraying. In this case the samples were moulded in the frame of special construction (Fig 1).

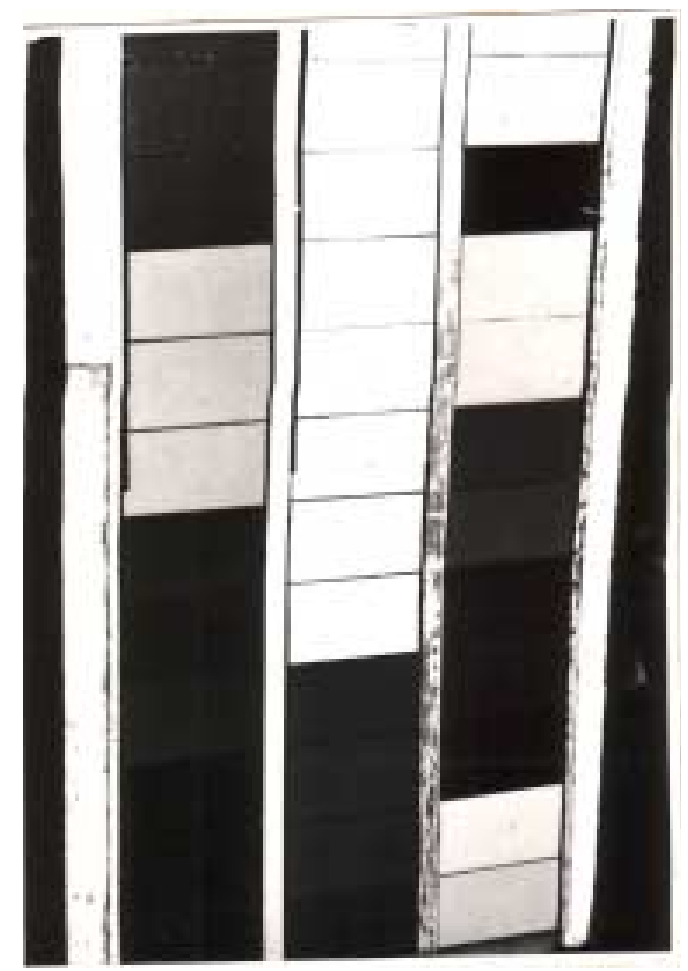

Fig 1. General view of tile layout for the experiment according to LST 1272:1992, p. 3.8.3

Before the cyclic experiment start according to LST 1413.12:1998 the fragment of ceramic tiles was sprayed with water for 3 days. One cycle of the experiment consists of the programmed model-type freezing (unilateral freezing) and thawing stages. The whole cycle duration $48 \pm 0,5 \mathrm{~h}$. The start begins with freezing. During freezing ceramic samples from one side the periodically alternating temperature was kept in the chamber $(24 \pm 0,25)$ h. Duration of an alternation period $(190 \pm 30) \mathrm{min}$, during which the samples were 7 times frozen and 6 times partially thawed. The temperature in the chamber at the end of the subperiod was $(-16 \pm 4){ }^{\circ} \mathrm{C}$, and at the end of the partial thawing $-(0 \pm 4){ }^{\circ} \mathrm{C}$. The freezing period was said to be finished after the $7^{\text {th }}$ freezing subperiod. Thawing duration of the experiment cycle was $(24 \pm 0,25)$ $\mathrm{h}$. At the beginning of thawing the finishing surface of the experimental fragment was sprayed for $(1-3) \mathrm{min}$ with the water of temperature $(15 \pm 5){ }^{\circ} \mathrm{C}$, later the experimental fragment $(16 \pm 4) \mathrm{h}$ was slowly thawed at the $(96 \pm 4) \%$ relative air humidity in the tightly closed section. At the end of the thawing stage the finishing surface of the experimental fragment was sprayed for $(6 \pm 2)$ $\mathrm{h}$ with water of $(15 \pm 5){ }^{\circ} \mathrm{C}$ temperature.
In this case the frost resistance test of ceramic tiles was carried out up to 125 cycles.

In this case the selected criteria for the frost resistance were: the residual surface (LM, \%) and the residual area (LP, \%).

Estimating the data obtained by the methods of mathematical statistics, the parameter of residual mass was equated to 100 ; if after 125 relative cycles the destruction of tiles was not observed, and the parameter of residual surface - 200 (correspondingly $100+100$ ).

\section{Discussion of research results}

\subsection{Analysis of criteria of ceramic tiles destruction processes}

Destruction of the ceramic product under investigation is related to the water saturation of pore volume and depends on the water migration and on the water phase transition processes. Hence water saturation of pore volume defines the frost resistance of ceramic products $[3,21]$. For such an estimation of service frost resistance the temperature-moisture regime applied in the experiments is important.

Primary destruction of ceramic tiles frozen according to LST 1272:1992, p. 3.8.3 was different.

From Table 1 one can see that the tiles under investigation have sufficient frost resistance. Destruction was not noticed in some samples $(22,31)$ even after 600 cycles of freezing and thawing. The data presented in Table 1 show that the sample No 18 started to disintegrate after cycles of unilateral freezing-thawing by

Table 1. Characteristics of ceramic tiles destruction

\begin{tabular}{c|c|l}
\hline \multirow{2}{*}{$\begin{array}{c}\text { No of } \\
\text { sample }\end{array}$} & \multicolumn{2}{|c}{$\begin{array}{c}\text { Unilateral freezing and thawing according to LST } \\
\text { 1272:1992 }\end{array}$} \\
\cline { 2 - 3 } & $\begin{array}{c}\text { Primary destruction } \\
\text { cycle }\end{array}$ & \multicolumn{1}{|c}{ Type of destruction } \\
\hline 1 & 149 & $\begin{array}{l}\text { Split of glaze together with } \\
\text { ceramic body }\end{array}$ \\
\hline 3 & 101 & Split of glaze \\
\hline 4 & 51 & $\begin{array}{l}\text { Flaking glaze off a ceramic } \\
\text { body }\end{array}$ \\
\hline 15 & 116 & Cracking of ceramic body \\
\hline 18 & 41 & Crumble of ceramic body \\
\hline 19 & 192 & $\begin{array}{l}\text { Continuous crack in } \\
\text { ceramic body }\end{array}$ \\
\hline 22 & 600 & No changes observed \\
\hline 24 & 83 & Split of glaze \\
\hline 25 & 333 & Split of glaze \\
\hline 27 & 40 & $\begin{array}{l}\text { Split of glaze together with } \\
\text { ceramic body }\end{array}$ \\
\hline 29 & 502 & $\begin{array}{l}\text { Flaking glaze off a ceramic } \\
\text { body }\end{array}$ \\
\hline 31 & 600 & No changes observed \\
\hline
\end{tabular}


crumble the ceramic body. The sample No 19 started to destruct by a continuous cracking of the ceramic body.

The question remains how accurate and reliable is the evaluation of primary destruction symptoms determining the frost resistance. In addition, the primary destruction is hardly noticed with the naked eye. When the symptoms are not observed at a distance, they may be not fixed at all.

Continuing the cyclic freezing and thawing the cracks in the local destruction places of ceramic samples develop further on. The locality of destructions is different: it may be the facing side, but equally the opposite one.

Hence the symptoms of ceramic tiles primary destruction are various, however they characterise the service frost resistance only partially.

Various kinds of destruction are possible, the lattice forming or cracks appearing in glaze or ceramic body. Destruction is possible also due to pores in glaze, connected to the ceramic body. In other cases cracks of any orientation appear in the body. Such cracks lead to segregation, split or spall together with the whole ceramic body.

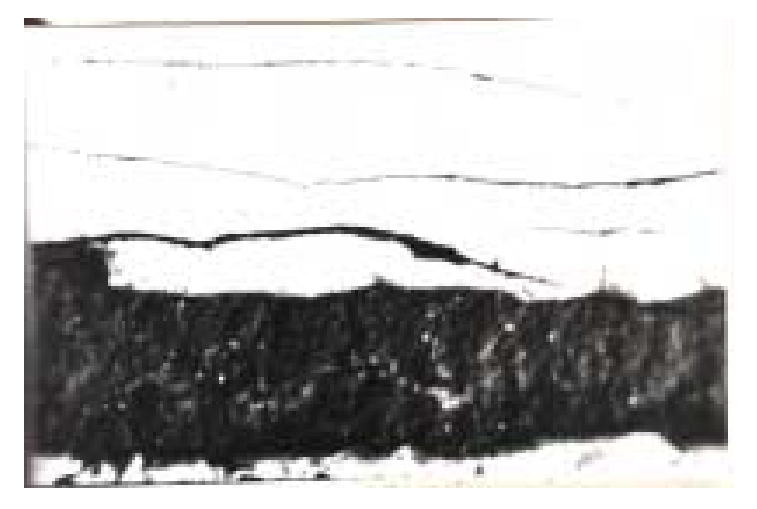

Fig 2. Picture of typical finishing surface destruction of glazed ceramic tile

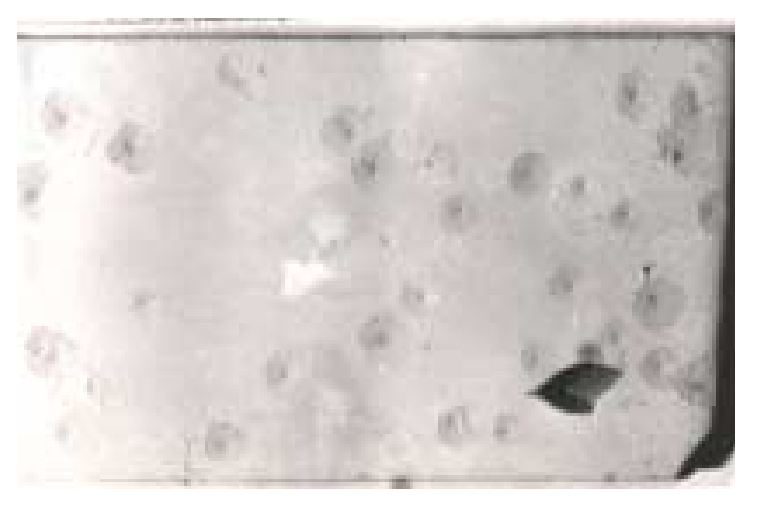

Fig 3. General picture of finishing surface of the glazed tile No 24 after 600 cycles of unilateral freezing according to LST 1272:1992, p. 3.8.3
The typical result of finishing surface destruction of glazed ceramic tile is presented in Fig 2. In this case appearance of cracking and at the same time flaking of glaze from the ceramic body is observed.

For an objective estimation of frost resistance of ceramic tiles it is needed to record not only the beginning of destruction and its character, but also the final destruction of the frozen surface.

An additional case of glazed ceramic tile destruction is presented in Fig 3. It shows that the split of glaze has taken place in many spots in the tile No 24. Such splits may be integrated with development of glaze flaking or crumble of ceramic body. Although it proceeds in many spots, the measured destruction area is not big and the mass losses are quite small as well.

Tendencies of ceramic tiles destruction are presented in Table 2. The case presents the data when experiments were carried out according to LST 1413.12:1998.

The destructions observed are characteristic of both glazed and unglazed tiles under simulated extremely unfavourable natural conditions.

Table 2 shows that the primary destruction symptoms may appear in one or several spots.

Table 2. Symptoms of primary destruction of ceramic tiles and their characteristics

\begin{tabular}{c|c|c|c|c}
\hline $\begin{array}{c}\text { No of } \\
\text { sample }\end{array}$ & $\begin{array}{c}\text { Characteristic of primary } \\
\text { destruction }\end{array}$ & $\begin{array}{c}\text { Increase } \\
\text { of water } \\
\text { saturation } \\
\text { after 35 } \\
\text { cycles }\end{array}$ & $\begin{array}{c}\text { Damage } \\
\text { of } \\
\text { festruction } \\
\text { cycle } \\
\text { surface } \\
\text { after 35 } \\
\text { cycles, \% }\end{array}$ \\
\hline 1 & $\begin{array}{c}\text { Description of } \\
\text { primary } \\
\text { destruction }\end{array}$ & No changes & 2,93 & Absent \\
\hline 3 & 19 & $\begin{array}{c}\text { Split of glaze } \\
\text { in 1 spot }\end{array}$ & 1,58 & 0,091 \\
\hline 4 & 14 & $\begin{array}{c}\text { Split of glaze } \\
\text { in 5 spots }\end{array}$ & 2,06 & 0,160 \\
\hline 7 & 12 & $\begin{array}{c}\text { Lattice of } \\
\text { microcracks } \\
\text { in glaze }\end{array}$ & 1,37 & 1,428 \\
\hline 9 & 15 & $\begin{array}{c}\text { Lattice of } \\
\text { microcracks } \\
\text { in glaze in 2 } \\
\text { spots }\end{array}$ & 1,22 & 4,000 \\
\hline 10 & 20 & $\begin{array}{c}\text { Split of glaze } \\
\text { in 4 spots }\end{array}$ & 1,38 & 0,286 \\
\hline 16 & No changes & 1,30 & Absent \\
\hline
\end{tabular}

Table 2 shows that the sample 3 starts to destruct when the glaze splits in a spot. The sample 4 starts destructing when the glaze splits in several spots. The data presented show that the type of destruction may differ as well. Samples 7 and 9 show the lattice of microcracks in the glaze.

After 35 cycles of freezing and thawing different tendencies of ceramic tile surface destruction are 
observed. The surface of the sample 4 was destructed by $0,160 \%$ after 35 cycles, in the sample 9 after 35 cycles of freezing and thawing by $4 \%$. In this case not only the primary destruction symptoms of ceramic tiles differ, but also further destruction tendencies.

As the results show (Table 2), the increase in water absorption is observed in all cases. Though it is not directly linked with the destruction process, leastwise it takes place in the beginning of experiment (after 35 cycles).

The primary destruction symptoms observed were completely similar when performing the experiment by both unilateral freezing and thawing methods.

In Fig 4 we can see that the destruction of samples (in case of glazed tile) started by the split of glaze in one spot. After 125 cycles of unilateral freezing according to LST 1413.12:1998 the glazing ceramic tile was destructed only in one corner.

Destruction of glazed ceramic tiles took place not only on the finishing side, but also on the opposite one. This can be seen in Fig 5. In case of tile No 3 a larger destruction surface was recorded in the surface opposite to the finishing one.

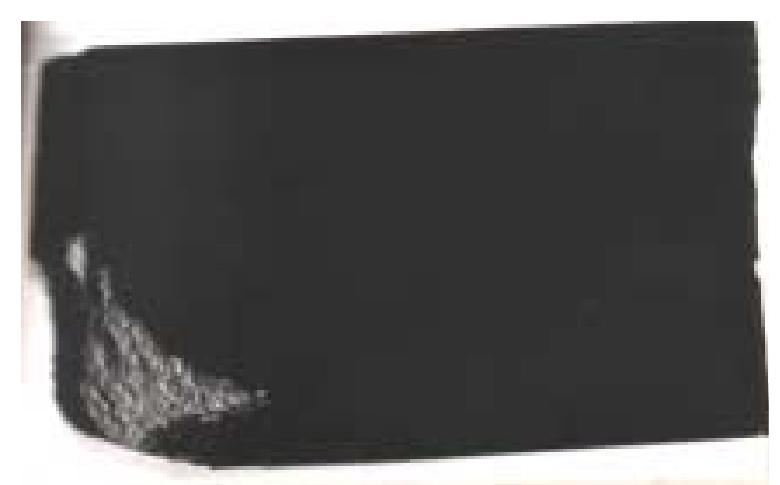

Fig 4. Picture of finishing surface of the glazed ceramic tile No 3 after 125 cycles of freezing and thawing according to LST 1413.12:1998

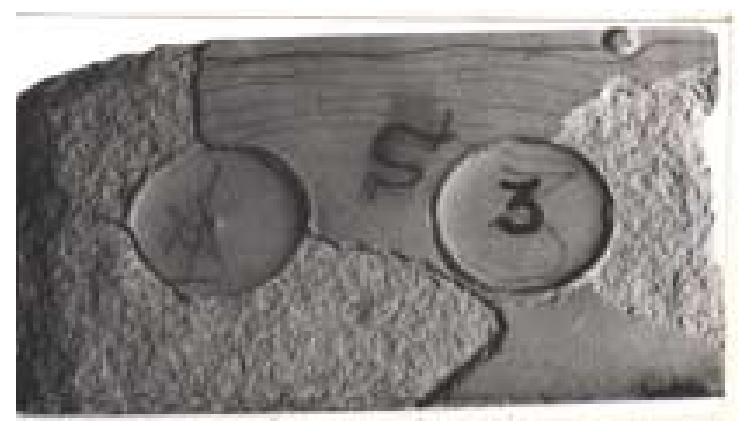

Fig 5. Picture of the glazed ceramic tile No 3 from the opposite side after 125 cycles of freezing and thawing according to LST 1413.12:1998
In Fig 6 we can see that for the other sample the flaking of glaze with ceramics is characteristic of the central part.

Thus we observe the localised destruction processes in different spots: in one case in the corner of the glazed ceramic tile, in the other case - in the middle of such a tile. The destruction process begins and proceeds in the weakest spots. This is related to the unevenness and inhomogeneity of a ceramic body. It may happen that in these cases the adhesion of glaze to ceramic body is uneven.

The picture of high quality glazed ceramic tile is presented in Fig 7. In such a tile the destruction symptoms are not observed even after 125 cycles of unilateral freezing according to LST 1413.12:1998. This tile is of high quality and it determines the mechanical and structural properties of the ceramic body itself. The glazed ceramic tiles of this type may be applied even under the most unfavourable conditions in Lithuania.

Analysing the determined tendencies it may be stated that processes taking place in ceramic tiles freezing them according to LST 1272:1992, p. 3.8.3, and to LST 1413.12:1998 have essential similarities.

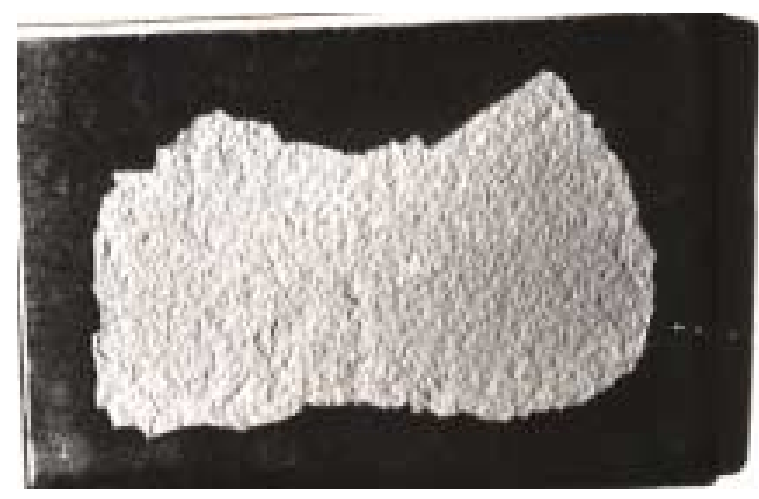

Fig 6. Picture of finishing surface of the glazed tile No 29 after 125 cycles of unilateral freezing and thawing according to LST 1413.12:1998

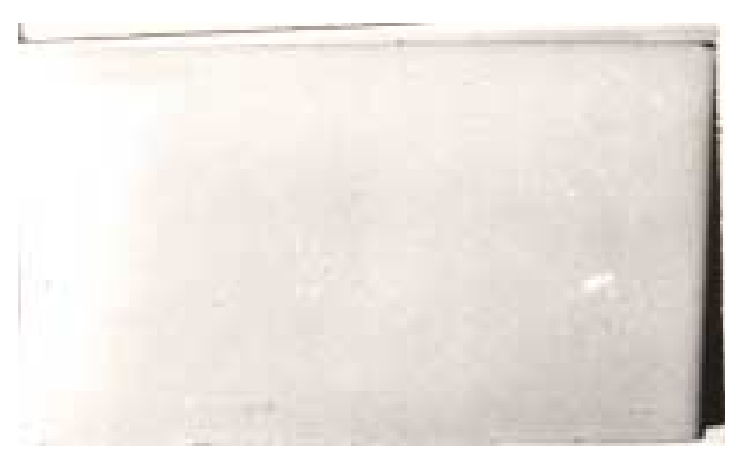

Fig 7. Picture of the sample No 25 after 125 cycles of unilateral freezing and thawing according to LST 1413.12:1998 
As shown in Figs 2-7, the destruction surface and destruction mass may be determined for all glazed or unglazed ceramic tiles under investigation, as well as residual mass and residual surface analogously. Such criteria for destruction evaluation were applied for further analysis.

\subsection{Interdependence of destruction and structural parameters of ceramic tiles}

Applying methods of mathematical statistical analysis the investigation of ceramic tiles structural and destructive parameters was performed.

There is a direct relationship between the frost resistance and the particular structural pore volume parameters of ceramic tiles. Increasing the parameter of reserve of pore volume in ceramic products, the parameter of service frost resistance increases as well [3, 21]. This is proved by the results of investigation in ceramic products that conform to the effect of freezing water under simulated and natural conditions.

This is also seen from Table 3. The sample of ceramic tile No 27 started to destruct in the cycle 40, and the value of its pore volume parameter is $16,67 \%$. In this case the sample of ceramic tile No 31 resisted more than 600 cycles of unilateral freezing-thawing, and the value of its pore volume is $45,13 \%$.

Namely using this parameter it is possible to predict the service frost resistance of a ceramic product. The bigger is the water saturation of pore volume in the initial stage, the less freezing and thawing may resist the samples without symptoms of destruction.

Coefficients of pair correlation of the analysed parameters are presented in Table 4.

The bigger is the residual surface and residual mass, the more frost resistant is such a ceramic tile. A tendency is observed: the less is the destruction mass and surface of the frozen ceramic tile, the more such samples are frost resistant. This can be seen from the data in Table 3. The residual mass of the sample No 27 is 50,03

Table 3. Characteristic destructive and structural parameters of ceramic tiles

\begin{tabular}{|c|c|c|c|c|c|c|c|c|c|c|}
\hline \multirow{2}{*}{$\begin{array}{c}\text { No of } \\
\text { samples }\end{array}$} & \multicolumn{5}{|c|}{ Destructive parameters of ceramic tiles } & \multicolumn{5}{|c|}{ Structural parameters of ceramic tiles } \\
\hline & $\begin{array}{l}\mathrm{FV}, \\
\text { cycles }\end{array}$ & LM, \% & LP, \% & $\mathrm{MN}, \%$ & $\mathrm{PN}, \%$ & $\mathrm{R}, \%$ & $\begin{array}{l}\mathrm{N}, \\
\text { units }\end{array}$ & $\begin{array}{c}\mathrm{G}, \\
\mathrm{g} / \mathrm{cm}^{2}\end{array}$ & $\begin{array}{l}\mathrm{H}, \\
\mathrm{cm}\end{array}$ & $\begin{array}{c}\mathrm{X}_{120} \\
\mathrm{~g} / \mathrm{cm}^{2} \mathrm{~s}^{0,5}\end{array}$ \\
\hline 9 & 39 & 85,60 & 122,5 & 34,09 & 41,8 & 26,22 & 0,43 & 0,27 & 1,9 & 0,0062 \\
\hline 20 & 49 & 82,89 & 117,80 & 39,62 & 18,3 & 24,54 & 1,00 & 0,23 & 1,30 & 0,0059 \\
\hline 27 & 40 & 50,03 & 6,6 & 83,17 & 73,60 & 16,67 & 0,43 & 0,44 & 2,2 & 0,0102 \\
\hline 24 & 83 & 98,73 & 195,50 & 0,56 & 29,10 & 31,22 & 0,75 & 0,15 & 1,10 & 0,0034 \\
\hline 3 & 101 & 86,79 & 132,50 & 36,30 & 39,50 & 24,10 & 3,00 & 0,22 & 1,30 & 0,0056 \\
\hline 8 & 116 & 89,98 & 137,3 & 23,37 & 6,9 & 26,28 & 0,40 & 0,26 & 1,7 & 0,0061 \\
\hline 1 & 149 & 98,91 & 130,30 & 10,8 & 3,90 & 27,45 & 1,17 & 0,39 & 2,4 & 0,0088 \\
\hline 35 & 313 & 86,37 & 150 & 0,2 & 1,7 & 30,92 & 0,83 & 0,20 & 1,5 & 0,0049 \\
\hline 29 & 502 & 88,51 & 131,4 & 3,45 & 2,6 & 30,59 & 2,0 & 0,20 & 1,4 & 0,0046 \\
\hline 31 & 600 & 100 & 200 & 0 & 0 & 45,13 & 0,5 & 0,07 & 0,4 & 0,0017 \\
\hline
\end{tabular}

Table 4. Matrix of pair correlation coefficients of destructive and structural parameters of ceramic tiles

\begin{tabular}{c|c|c|c|c|c|c|c|c|c|c|c}
\hline & $\mathrm{X}_{120}$ & $\mathrm{U}$ & $\mathrm{R}$ & $\mathrm{D}$ & $\mathrm{H}$ & $\mathrm{N}$ & $\mathrm{G}$ & $\mathrm{LM}$ & $\mathrm{LP}$ & $\mathrm{MN}$ & $\mathrm{PN}$ \\
\hline $\mathrm{X}_{120}$ & 1 & $-0,61^{*}$ & $-89^{*}$ & 0,09 & $0,93^{*}$ & $-0,08$ & $0,99^{*}$ & $-0,78^{*}$ & $-0,84^{*}$ & $0,72^{*}$ & $0,64^{*}$ \\
\hline $\mathrm{U}$ & - & 1 & $0,67^{*}$ & $-0,02$ & $-0,57^{*}$ & 0,05 & $-0,58^{*}$ & $0,36^{*}$ & $0,46^{*}$ & $-0,33$ & $-0,26$ \\
\hline $\mathrm{R}$ & - & - & 1 & $-0,11$ & $-0,78^{*}$ & $-0,03$ & $-0,85^{*}$ & $0,79 *$ & $0,86^{*}$ & $-0,74^{*}$ & $-0,65^{*}$ \\
\hline $\mathrm{D}$ & - & - & & 1 & 0,03 & $-0,15$ & 0,06 & $-0,30$ & $-0,28$ & 0,18 & 0,14 \\
\hline $\mathrm{H}$ & - & - & - & - & 1 & $-0,16$ & $0,95^{*}$ & $-0,63^{*}$ & $-0,75^{*}$ & $0,55^{*}$ & $0,50^{*}$ \\
\hline $\mathrm{N}$ & - & - & - & - & - & 1 & $-0,10$ & 0,12 & 0,15 & 0,01 & 0,05 \\
\hline $\mathrm{G}$ & - & - & - & - & - & - & 1 & $-0,74^{*}$ & $-0,83^{*}$ & $0,69^{*}$ & $0,62^{*}$ \\
\hline $\mathrm{LM}$ & - & - & - & - & - & - & - & 1 & $0,94^{*}$ & $-0,80^{*}$ & $-0,70^{*}$ \\
\hline $\mathrm{LP}$ & - & - & - & - & - & - & - & - & 1 & $-0,76^{*}$ & $-0,70^{*}$ \\
\hline $\mathrm{MN}$ & - & - & - & - & - & - & - & - & - & 1 & $0,90^{*}$ \\
\hline $\mathrm{PN}$ & - & - & - & - & - & - & - & - & - & - & 1 \\
\hline
\end{tabular}

* meaningful parameters 
$\%$, the residual area very small $-6,6 \%$. In this case the surface of the destructed area of ceramic tile is $73,60 \%$ and the destructed mass $-83,17 \%$. In other case the ceramic tile No 29 resisted 502 cycles of unilateral freezing and thawing, determined according to LST 1272:1992, p. 3.8.3. Here the residual area of ceramic tile reaches $131,4 \%$, residual mass of the sample is $88,51 \%$. Thus the destructed area of the tile reaches only $2,6 \%$, and the destructed mass is $3,45 \%$.

The data in Table 4 show that correlation coefficients between the parameter of residual mass LM and the reserve of pore volume $\mathrm{R}$ is 0,79 , and between the parameter of residual area and $\mathrm{R}$ is 0,86 . Whereas correlation coefficients between the parameter of destruction mass $\mathrm{MN}$ and the reserve of pore volume parameter $\mathrm{R}$ is 0,74 , between the parameter of destruction area PN and $\mathrm{R}-0,65$.

One of the new parameters is $\mathrm{X}_{120}$. It correlates strongly both with the parameter of reserve of pore volume $\mathrm{R}$ and with the parameters of residual mass LM and residual area LP. Coefficients of pair correlation are correspondingly $-0,89,-0,78,-0,84$.

Physical meaning of the parameter $\mathrm{X}$ is that it demonstrates the actual, effective equivalent radius or diameter of pores and capillaries of ceramic tiles.

Whereas $U$ defines the alternation of effective pores and capillaries radius or diameter in the product. Correlation of this parameter with the residual mass and residual area is meaningful. Coefficients of pair correlation are correspondingly 0,36, 0,46 (Table 4).

Analysing the structural parameters the intercorrelation is observed. Especially strong correlation is between the parameters $\mathrm{X}_{120}$ and $\mathrm{G}$ (Table 4).

It may be presumed that the parameter $\mathrm{X}_{120}$ together with the parameter $U$ may change the parameters $G, N$ to some degree in prediction of the service frost resistance.

\subsection{Equations for predicting the residual mass and residual surface of ceramic tiles}

When predicting the service frost resistance of ceramic tiles it was decided to forecast the residual surface and the residual mass of the samples. In this case the frost resistance of ceramic tiles was determined according to LST 1413.12:1998. It corresponds to the most unfavourable aggressive service conditions.

When performing the investigation there was no possibility to analyse the anisotropy of product structure as the product is a thin wall. An other problem occurredno possibility to make a capillary suction from the finishing surface side because of glaze covering, therefore the experiment was made only from the opposite side. Analysing the character of product destruction some differences of ceramic tiles destruction from the finishing and the opposite side are noticed. For solving the problem new structural parameters were selected: diameter of pores and capillaries $\left(\mathrm{X}_{120}\right)$ and unevenness of effective pores and capillaries in the product $(\mathrm{U})$; together with the known parameters: reserve of pore volume $(\mathrm{R})$, relative wall thickness of pores and capillaries (D); amount of water sucked by capillaries under normal conditions (G) and parameter of structural inhomogeneity (N).

It was important to determine the empiric relation between the residual surface, mass of ceramic tiles and the structural parameters. For evaluation these parameters were selected: in one case $\mathrm{R}, \mathrm{D}, \mathrm{X}_{120}, \mathrm{U}$, in another case - R, D, G, N.

In the first case such interdependence between the parameter of residual mass LM and the structural parameters $\mathrm{R}, \mathrm{D}, \mathrm{X}_{120}$, $\mathrm{U}$ was derived:

$$
L M=100 \cdot\left(1-\frac{e^{6,982} D^{0,222} U^{0,27} X_{120}^{0,479}}{R^{2,336}}\right) .
$$

Equation (3) $\mathrm{R}=0,93$. Variance explained: $86,86 \%$.

Such interdependence between the parameter of residual area LP and the structural parameters R, D, X120, $\mathrm{U}$ was determined as

$$
L P=200 \cdot\left(1-\frac{e^{6,095} D^{0,159} U^{0,116} X_{120}^{0,699}}{R^{1,267}}\right) .
$$

Equation (4) $\mathrm{R}=0,92$. Variance explained: $85,14 \%$.

For the second case the interdependence of the residual mass and the aforementioned structural parameters was derived:

$$
L M=100 \cdot\left(1-\frac{e^{5,705} \cdot D^{0,124} G^{0,083}}{R^{2,385} N^{0,199}}\right) .
$$

Equation (5) $\mathrm{R}=0,93$. Variance explained: $86,45 \%$.

Also the interdependence between the residual surface and the structural parameters R, D, N and G was derived:

$$
L P=200 \cdot\left(1-\frac{e^{3,918} \cdot D^{0,105} G^{0,449}}{R^{1,387} \cdot N^{0,175}}\right) \cdot
$$

Equation (6) $\mathrm{R}=0,93$. Variance explained: $86,89 \%$.

It is possible to predict the residual surface and mass applying one or another structural parameters both by using Eqs 3 and 4, or 5 and 6, when the tiles are applied under the conditions of FIII category.

It is obvious that Eqs 3-6 perfectly suit for prediction of the service frost resistance according to the residual mass and the residual surface; taking into account the actual values of multiple correlation coefficient and dispersion from empirical equations it may be implemented quite exactly. The equations derived are significant. These equations show which parameters largely influence the parameter of service frost resistance.

As for all ceramic products, the common tendency for ceramic tile is observed: the bigger is the parameter of reserve of pore volume, the more frost resistant are such products. 
Comparing Eqs 3 and 4 with 5 and 6 it may be noticed that location of pores and capillaries radius or equivalent diameter parameter X120 and effective pores and capillaries radius or parameter of diameter range in a product $U$ and parameter of amount of water sucked $G$ in equations are analogous. This tendency may be partially explained by their significant interdependence (Table 4).

As smaller effective pores and capillaries prevail in these ceramic tiles and the more even is their distribution, the more such ceramic tiles are frost resistant under the simulated service conditions. Also they absorb less water and therefore resist the destructive aggressive impact of water transition during freezing.

For the rapid estimation of the service frost resistance of ceramic tiles, both the empirical equations 3 and 4 , or 5 and 6 may be applied. These equations are derived for the ceramic tiles with open porosity less than $26 \%$.

The common tendency is that the objectivity of the rapid determination of the service frost resistance of ceramic tiles increases when the attention is paid not only to the reserve of pore volume, but also to other important structural parameters of ceramic tile.

\section{Conclusions}

1. When investigating ceramic tiles, it has been determined that the primary destruction symptoms are the lattice of microcracks and the splits of various configuration and layout, parallel as well as perpendicular to the direction of heat offtake direction. While pore volume fills with water further on, the symptoms proceed destructing the glaze, ceramic body or the glaze together with the ceramic body.

2. It has been determined that according to the primary symptoms of ceramic tile destruction it is possible to predict further destruction tendencies in the ceramic product. New criteria of the service frost resistance estimation have been offered and applied: the residual mass and the residual surface.

3. For a rapid determination of the service frost resistance of ceramic tiles it is possible to use new structural parameters (parameter of pores and capillaries radius or diameter $\mathrm{X}_{120}$ and parameter of unevenness of effective pores and capillaries in the product $\mathrm{U}$ ).

4. Determining the residual area and the residual mass for the objective and rapid estimation of the service frost resistance of ceramic tiles not only the reserve of pore volume, but also the other structural parameters should be applied when the foreseen service conditions are extremely unfavourable.

\section{References}

1. Mačiulaitis, R.; Nagrockienè, D. and Kičaite, A. Cold endurance of ceramic facing. Glass and ceramics (Стекло и керамика), № 4, 2003, p. 25-28 (in Russian).
2. Mačiulaitis, R. and Remeikienè, G. Questions of durability of ceramic facing. Building materials (Строительные материалы), № 6, 1991, p. 24-25 (in Russian).

3. Mačiulaitis, R. Frost resistance and durability of ceramic facade products (Морозостойкость и долговечность изделий фасадной керамики). Vilnius: Technika, 1997. 308 p. (in Russian).

4. Brüning, H. Frost resistance of bricks. Brick and tile industry international (Ziegelindustrie International), No 11, 1987, p. 570-575 (in German).

5. Brüning, H. Frost resistance of masonry bricks. Brick and tile industry international (Ziegelindustrie International), No 10,1987 , p. 502-503 (in German).

6. Sadūnas, A. Durability of aluminum silicate products (Aliumosilikatinių dirbinių ilgaamžiškumas). Vilnius: VPU, 1997. 252 p. (in Lithuanian).

7. Ritchie, T. The method of freezing bricks: its influence on their durability. J. Canad. Ceram. Soc. Vol 44, 1975, p. 2122.

8. Nakamura, M.; Togaya, T. and Okuda, S. Effects of dimensional distribution of pores in porous ceramic on frost resistance under one dimensional cooling. J. Ceram. Soc. Japan, Vol 85, No 987, 1977, p. 549-553.

9. Van der Velden, Jan H. Weathering and frost testing of structural ceramics. Brick and tile industry international (Ziegelindustrie International), No 1, 1983, p. 18-26.

10. West, H.; Ford, R. and Poeake F. A panel freezing test for brickwork. Brit. Ceram. Soc. Transaction and Journal, Vol 83, 1984, p. 112-115.

11. Sadūnas, A. and Bure, D. Water migration processes in heavy clay ceramics under freezing-thawing cycles. Tile Brick Int., Vol 15, No 4, 1999, p. 238-240, 242-245.

12. LST 1413.12:1998. Mortar. Methods of experiment. Determination of frost resistance of plaster and other finishing by the method of unilateral freezing (Statybinis skiedinys. Bandymo metodai. Tinko ir kitokios apdailos atsparumo šalčiui nustatymas vienpusio šaldymo būdu) (in Lithuanian).

13. Franke, L. and Bentrup, H. The consideration of frost resistance of bricks taken in long. Brick and tile industry international (Ziegelindustrie International), No 9, 1993, p. 483-492 (in German).

14. Maage, M. Frost resistance and distribution of porous in bricks. Brick and tile industry international (Ziegelindustrie International), No 9, 1990, p. 472-480 (in German).

15. Sadunas, A.; Bure, D. and Matschjulaitis R. New about frost resistance in ceramic products. In: Proc of 12th International Conference Building materials, Vol 2, Weimar, 1994, p. 221-231 (in German).

16. Maciulaitis, R. Frost resistance and long service life of ceramic faēade products. Part 4. Brick and tile industry international (Ziegelindustrie International), No 7-8, 1995, p. 474-486.

17. Maciulaitis, R. Frost resistance and long service life of ceramic faēade products. Part 5. Brick and tile industry international (Ziegelindustrie International), No 7, 1997, p. $427-433$.

18. Franke, L. and Bentrup, H. Evaluation of the frost resistance of bricks in regard to long service life, 1. Brick and tile industry international, No 7-8, 1993, p. 483-492. 
19. Kičaite, A. The development of methods for rapid prediction of frost resistance of ceramic products. Civil Engineering (Statyba), Vol V, No 3, 1999, p. 222-228 (in Lithuanian).

20. Mačiulaitis, R. and Kičaitè, A. New possibilities for rapid predicting the frost resistance of facade ceramics. Materials science, Vol 8, No 4, 2002, p. 469-472.

21. Kičaitè, A. and Mačiulaitis, R. The service frost resistance aspect of water absorption kinetics in ceramic products. Journal of Civil Engineering and Management, Vol VIII, Suppl 2, 2002, p. 126-131.

22. Šveda, M. The effect of firing temperature and dweel time on the frost resistance of clay roofing tile. Brick and tile industry international (Ziegelindustrie International), No 6, 2004, p. 36-43.

23. Šveda, M. and Uncik, S. Influence of pore structure on the frost resistance of brick products. Brick and tile industry international, No 7, 1999, p. 80-85.
24. Freyburg, S. and Finger, F.A. Microstructure formation and durability of bricks. Brick and tile industry international (Ziegelindustrie International), Vol 54, No 5, 2001, p. 32-42.

25. Friese, P. Predictions of the frost resistance of bricks. Brick and tile industry international (Ziegelindustrie International), Vol 48, No 12, 1995, p. 952-963.

26. Robinson, G. C.; Butler, D. and Smalley, A. Predicting brick frost resistance. Am. Ceram. Soc. Bull, Vol 74, No 10, 1995, p. 64-69.

27. Beliakov, A. V. and Zacharov, A. I. The increase of frost resistance of wall ceramics. Glass and ceramics (Стекло и керамика), № 3, 1997, p 12-15 (in Russian).

28. Amoroso, G.G. and Fasina, V. Stone decay and conservation. Amsterdam - Lausanne - Oxford New York, 1983.

29. LST 1272:1992 Ceramic bricks. Technical conditions (Keraminès plytos. Techninès sąlygos) (in Lithuanian). 